
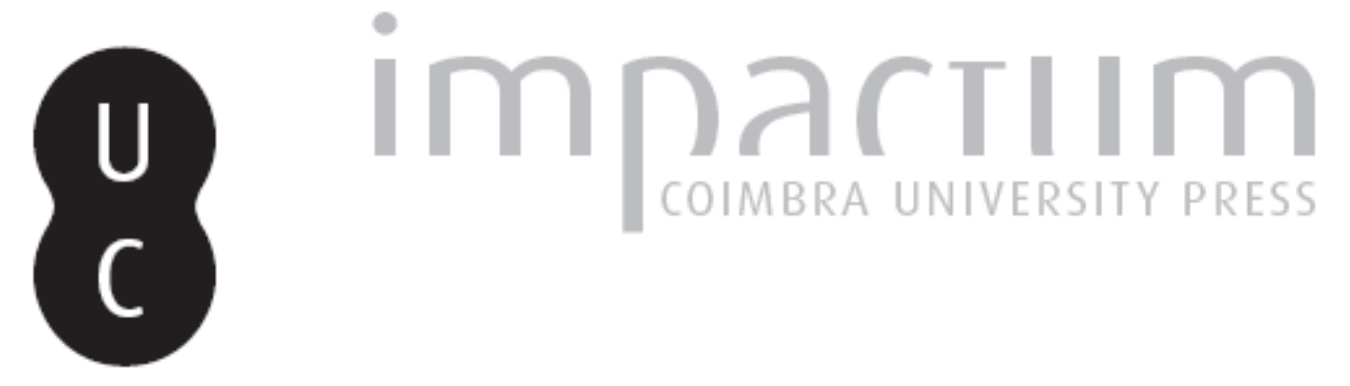

Joaquim de Carvalho: o clerc universitário

Autor(es): $\quad$ Carvalho, Paulo Archer de

Publicado por: Imprensa da Universidade de Coimbra

URL persistente:

URI:http://hdl.handle.net/10316.2/42753

DOI:

DOI:https://doi.org/10.14195/1647-8436_46_47_6

Accessed : $\quad$ 26-Apr-2023 10:03:25

A navegação consulta e descarregamento dos títulos inseridos nas Bibliotecas Digitais UC Digitalis, UC Pombalina e UC Impactum, pressupõem a aceitação plena e sem reservas dos Termos e Condições de Uso destas Bibliotecas Digitais, disponíveis em https://digitalis.uc.pt/pt-pt/termos.

Conforme exposto nos referidos Termos e Condições de Uso, o descarregamento de títulos de acesso restrito requer uma licença válida de autorização devendo o utilizador aceder ao(s) documento(s) a partir de um endereço de IP da instituição detentora da supramencionada licença.

Ao utilizador é apenas permitido o descarregamento para uso pessoal, pelo que o emprego do(s) título(s) descarregado(s) para outro fim, designadamente comercial, carece de autorização do respetivo autor ou editor da obra.

Na medida em que todas as obras da UC Digitalis se encontram protegidas pelo Código do Direito de Autor e Direitos Conexos e demais legislação aplicável, toda a cópia, parcial ou total, deste documento, nos casos em que é legalmente admitida, deverá conter ou fazer-se acompanhar por este aviso. 


\section{BOLETIM DA \\ BIBLIOTECA GERAL DA UNIVERSIDADE DE COIMBRA}

VOL. 46/47 (2015/2016)

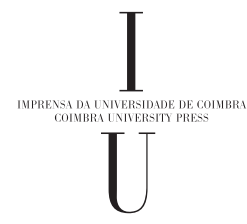




\title{
Joaquim de Carvalho: o clerc universitário'
}

\author{
Paulo Archer de Carvalho²
}

\section{RESUMO}

Professor, bibliotecário, bibliólogo, editor universitário, Joaquim de Carvalho (1892-1958) é investigador e autor pioneiro, entre nós, de uma historiografia cultural de matriz filosófica e da história das ideias, tal como a esboçaram Windelband e Dilthey no ocaso e na transição do século XIX e se praticara, com Collingwood, na primeira metade do século XX.

No fulcro dessa longa duração que sinaliza afinal a viragem para a agonia eurocêntrica e durante a qual a intelectualidade europeia mais se cindiu sobre o seu próprio estatuto - arguição cuja peça-chave é o célebre manifesto polémico La Trahison des clercs, de Julian Benda - Joaquim de Carvalho

1 O presente artigo remete sistematicamente para CARVALHO, Paulo Archer de - Uma autobiografia da razão : A matriz da historiografia cultural de Joaquim de Carvalho. Coimbra : Imprensa da Universidade, 2015, do qual, em grande medida, adapta e circunscreve a parte final do I cap.; e remete, nalguma informação adicional, para Cartas de Joaquim de Carvalho para Alfredo Pimenta: 1922-1936. Coimbra: Imprensa da Universidade, 2016; e também para «Joaquim de Carvalho: da memória judaica ao esquecimento da Shoah». In Judeus Portugueses no Mundo: Pensamento, Medicina e Cultura. (Actas do Colóquio internacional). Universidade do Minho, 2014.

Para uma visão sinóptica do historiador da Cultura, cf. a nossa entrada «Joaquim de Carvalho». In Dicionário dos historiadores Portugueses desde a fundação da Academia Real de História até 1974, ee: http://dichp.bnportugal.pt/index.htm. A indicação bibliográfica da Obra completa (OC) de Joaquim de Carvalho, remete para a edição de Lisboa : Fundação Calouste Gulbenkian, 1978-1997, VIII+I vols., organização e introduções a cargo de José Vitoriano Pina Martins.

O autor escreve de acordo com a ortografia portuguesa; e em desacordo, portanto, com o ilógico Acordo que a descaracteriza e a impede de (se) pensar.

2 Centro de Estudos Interdisciplinares do Século XX - Universidade de Coimbra CEIS20-UC - pauloarcher33@yahoo.com.br 
patenteou o paradigma do clerc secular: Ou, se quisermos, do universitário que, avançando na episteme espinosiana, apenas se subjuga à sua própria consciência e que, à maneira kantiana, da sua livre ética da responsabilidade transforma em dever deontológico.

\title{
PALAVRAS-CHAVE
}

Joaquim de Carvalho (1892-1958); Universidade de Coimbra; Resistência intelectual ao salazarismo; História da Cultura.

\begin{abstract}
Professor, librarian, bibliologist and academic publisher, Joaquim de Carvalho (1892-1958) was a pioneer researcher and author of a cultural historiography of philosophical matrix and of the history of ideas, as outlined by Windelband and Dilthey at the end of the $19^{\text {th }}$ century and practiced by Collingwood in the first half of the 20th century.

At the fulcrum of this long period of time that marked the turning point to the Eurocentric agony and during which the European intelligentsia was most divided in its own status - an argument whose key piece is the famous controversial manifesto La Trahison des clercs by Julian Benda - Joaquim de Carvalho has patented the paradigm of the secular clerc: or, if we put it that way, the scholar who, advancing in Spinoza's episteme, only obeys to his own consciousness that, in the Kantian way, and according to his free ethics of responsibility, transforms it into a deontological obligation.
\end{abstract}

\section{KEYWORDS}

Joaquim de Carvalho (1892-1958); University of Coimbra; Intellectual resistance to Salazarism; History of Culture.

Na primeira meia centúria de vida das Faculdades de Letras, fundadas pela República em Lisboa e Coimbra (1911) e episodicamente no Porto (1919-1930), Joaquim de Carvalho ressalta como figura central do ensino e da investigação historiográfica da Filosofia em conexão com as fontes da História das ideias, só sendo possível cotejar, parcelarmente, no plano lógico-filosófico, ensaístico ou psicológico, com Vieira de Almeida, Edmundo Curvelo, Sílvio Lima ou, talvez, com Delfim Santos, que não exploram contudo análogas vias metodológicas. Como melhor o releu Miguel Baptista Pereira, num número evocativo 
da revista Biblos (LVI, 1980: 7-8), destruída já a procela autoritária, essa espécie de contra-revolução permanente, assentada a densa poeira do esquecimento e os fumos tóxicos que a temporalidade paradoxalmente arrasta e dissipa, o figueirense "agiganta-se no campo da produção universitária" do séc. XX, ao propor-se desvendar "a linguagem histórica que falamos" e ao evidenciar os "traços ainda ocultos da história cultural portuguesa".

Convalidações de idêntico teor, procedentes dos vários cantos do imaginário xadrez no qual as ideias (feitas peças, corpos e gente) se jogam, assegurar-lhe-iam um lugar único no complexo cultural português. Muito embora ideológica e politicamente situado nos antípodas, mas irmanado, com Paulo Merêa, na refutação do teor positivista e «objectivista» que hegemonizara a cultura universitária coimbrã, o jurista catedrático L. Cabral de Moncada, amigo e admirador de Carvalho, neste viu "o maior historiador da cultura portuguesa na sua expressão histórico-filosófica e filosófico-literária deste século" (Para a História da Filosofia em Portugal no século XX, 1960: 9). E um outro analista, mais atento então à coeva produção ibérica, achava na polígrafa inquirição da cultura portuguesa promovida pelo mestre universitário, apenas paralelo, na conjuntura historiográfica casteIhana e peninsular, na obra oitocentista do cantábrico Menéndez y Pelayo (Miscelânea de Homenagem a Joaquim de Carvalho, 1960: 346).

Embora a comum aspiração arqueológica e reconstitutiva de uma distinta mas irmanada tradição científica e cultural ibérica, o reconhecimento da determinante influência no estudo da Historia de los heterodoxos españoles, ou a insistência na investigação das fontes filosóficas autóctones, o pudessem indiciar, é certo que o casticismo concêntrico de Pelayo não se inscreve na generosa genealogia republicana, cosmopolita e liberal de Joaquim de Carvalho. Tanto mais que este afastava o sentido valorativo eminentemente pessoal e unitarista de Menéndez y Pelayo (OC, V: 212), assente num visão não iberista mas espanholista, redutora da multipolaridade cultural 
ibérica e aniquiladora do dualismo político no qual historicamente se cristalizara.

A analogia evidencia contudo o esforço incansável, ao um tempo, sistematizador e dispersivo, do investigador português. E o modo como, com passos seguros, o mestre alicerçou uma história das ideias, da qual foi bem o pioneiro representante no campo cultural (Fernando Catroga, "Joaquim de Carvalho e a História», Boletim da Biblioteca da Universidade de Coimbra, 42, 1994: 391-398), não apenas por ter explorado uma história dos conceitos, no sentido de certo modo académico, filológico e erudito, tal como fora explorado pela historiografia alemã, mas por ter proposto, nalguns passos, uma história por conceitos, da qual, exemplos maiores, a prospecção arqueológica em solo pátrio da ideia do republicanismo e o seu projecto nunca cumprido - tolhido pela própria morte - de uma História da Liberdade, representariam certamente o acume.

Ora, o seu maior mérito, enquanto historiador, foi o de ter destacado a intrínseca temporalidade do ente histórico, cujos actos e pensamentos só poderiam ser lidos à luz da totalidade das vivências, superando assim o velho programa metafísico e teleológico que ao Ser lhe assinalava um destino, porquanto os próprios ricorsi se encarregariam de the desmentir qualquer providencial caminho ou descaminho nos corsi históricos. E daí ter superado, com Dilthey, a aporia kantiana na "concepção do homem como ser racional de estrutura constante e idêntica" (OC, VIII: 19). Construtor de uma obra historiográfica densa, de grande coerência e solidez interna, pela meticulosa verificação dos pressupostos, pela certificação dos corolários e pela aferição das conclusões e, por isso, de intrínseca mestria deontológica, que assinala entre nós a passagem da escrita profissional da história-narrativa, por vezes por ele ainda praticada na década de 30 nalgumas laudas, à história-problemática, que o seduzirá cada vez mais, na construção poliédrica da historiografia da qual, como especialista algum do seu tempo, foi o artífice entre nós. 
Não será estranho, por isso, que Joaquim de Carvalho - jogando nos palcos díspares de uma cronologia muito vasta, grosso modo, dos séculos $\mathrm{XV}$ e $\mathrm{XVI}$ ao século $\mathrm{XIX}$ e mesmo aos inícios do século $X X$, coloque a historiografia crítica da filosofia e da cultura e nela, inclusive, das ciências, num patamar de exigência não antes conhecido - releia-se a sua Antheriana, ou a sua extraordinária introdução ao Livro I da Ética de Espinosa, por se fundar num trabalho minucioso, que nunca torturou as fontes para Ihes exigir confissões que não poderiam dar, e por desenvolver uma escrupulosa verificação a que o seu profundo saber filosófico, a mais-valia do historiador cultural, conferia nova densidade e possibilidades hermenêuticas.

Figuração exacta é aquela, hoje melhor perceptível, do clerc universitário, também, no modo como rebateu ao longo da vida, quer, na juventude, as tentações hegemónicas do jacobinismo radical, quer, na maturidade, as visões redutoras do partidarismo ou, noutra vertente, a clericalização, o espírito de cruzada e a «renacionalização» do vigiado programa cultural que a Universidade crescentemente veicularia a partir de 1928-32; quer, sobremodo, como contestou a ulterior autocracia policial do Estado Novo - uma eternidade (como se Ihe assemelhara) que não se dissipara quando os ventos libertadores e democráticos e a destruição do nazifascismo na Europa central e ocidental esbarrarem, por questões que não interessam aqui mas que decerto relevam duma história europeia insuficientemente indagada, com a intransponível cordilheira dos Pirenéus.

Por isso, Carvalho não se dobrará aos ditames do ditador, seu colega mais velho nas bancadas jurídicas, por mais que Salazar, passo a passo e ciente do enorme capital de liberdade ideativa que Carvalho entesourara e sabiamente redistribuía, Ihe vá roubando muito: em primeiro lugar, e como veremos em particular, a direcção da Biblioteca Geral (que acumulava com o secretariado editorial de $O$ Instituto de Coimbra) e a responsabilidade de edição da Revista da Universidade; depois, a administração e direcção da Imprensa da Universidade, 
extinta por decretais em 29-VIII-1934, onde criou notáveis colecções, quer de edições críticas de fontes - mormente nos corpos Scriptores rerum lusitanorum, incluídas as Crónicas; Biblioteca dos escritores portugueses; Subsídios para a história da arte portuguesa; Documentos para a história da expansão ultramarina dos Portugueses; Biblioteca do século XVIII; Biblioteca luso-brasileira de história da Medicina; ou ainda Arquivo de História e Bibliografia (1923-1926), editado postumamente em 1976; quer, no senso mais preciso, especializando a divulgação dos clássicos da filosofia política e, em geral, da literatura ético-filosófica (Biblioteca Democrática; Filósofos e Moralistas e Vária), experiência frutuosa continuada depois na Biblioteca Filosófica da Atlântida, editando e estimulando excelentes traduções portuguesas, algumas das quais assinadas por António Sérgio ou Vieira de Almeida, dalguns dos textos capitais de Kant, Montaigne, Descartes, Leibniz, Renouvier, Meumann, Croce, entre outros.

Mas, ao mesmo tempo, abria páginas e páginas de ensaios a novos autores portugueses, como Sílvio Lima, Adolfo Casais Monteiro, Agostinho da Silva, João Gaspar Simões, Newton de Macedo, Cruz Malpique, Saavedra Machado ou até João Ameal, o que lhe custará neste acaso, de resto, acirrada crítica do campo democrático, mormente aquela que o ex-presencista Albano Nogueira Ihe endereçou, acusando-o de abrigar os arautos do nacionalismo. O que originou a contra-resposta enérgica de Carvalho, nas páginas do lisboeta Diário Liberal que então co-dirigia (com Mário de Azevedo Gomes e Hernâni Cidade, entre outros), exprobando todos aqueles que supusessem que a defesa da cultura passaria tão-só pela defesa de uma visão sectária e redutora, eius, sua, ou mesmo pela partidarização do largo campo do espectro cultural.

Em todos os passos da vida profissional e da carreira académica, Joaquim de Carvalho foi intensamente um universitário: inscrito em Direito em Outubro de 1909 será bacharel por essa Faculdade (3-X-1914) e, depois, acumulando os dois cursos, desde 1911, licenciar-se-á com 
máxima distinção em Letras (19-X-1916), doutorando-se em Filosofia com dezanove valores (14-II-1917), teve o primeiro despacho como 2. assistente em 12-VIII-1916 e como professor ordinário em 5-XI-1919, ministrando um leque de cadeiras que incidiam sobre História da Filosofia Antiga, História da Filosofia Medieval, História da Filosofia Moderna, Moral, que serão as suas de referência, além de Pedagogia e de História da Educação, que regeu na Escola Normal Superior e depois na mesma Faculdade de Letras.

Muito jovem, desde 1918, director da Revista da Universidade de Coimbra, do Instituto de Filosofia (1926), do Laboratório de Psicologia Experimental (1938) e, de 1921 até à sua extinção, em 1930, da referida Escola Normal Superior, foi membro da comissão de reforma do Ensino secundário (em 1929), director da Biblioteca Geral da Universidade (de 1926 até 1931), administrador da Imprensa da Universidade desde 30 de Julho de 1921 até à sua extinção política, em Agosto de 1934, e depois, director da Biblioteca da Faculdade de Letras (despacho de 8-VIII-1934), o que poderíamos entender como compensação não compensada da dupla expulsão da direcção da Imprensa e da BGUC, Joaquim de Carvalho posteriormente seria conduzido a um dos cargos, com menor grau de autonomia e de decisão editorial e, sobretudo, menor visibilidade na cena política universitária e de responsabilidade cultural no quadro do país, de direcção das colecções Universitatis Conimbrigensis Studia ac Regesta e Acta Universitatis Conimbrigensis.

Por várias vezes secretário da Faculdade (desde 20-V-1921) reconduzido depois em 25-III-1940, nunca logrará contudo a direcção da sua Faculdade por claro embargo político exterior, apesar de ser internamente proposto. E nos anos 50, num pós-guerra afinal apaziguador para o Estado Novo, incapaz de fazer frente à nova revoada (após aquela, depuradora, dos anos 30) da «reconquista» nacionalista na universidade, perde posições internas quando, nos fora internacionais, mormente os que falam as línguas hispânicas e francesa, mais é 
reconhecido - em Abril de 1954 é proposto doutor honoris causa pela Faculdade de Filosofia da Universidade de Salamanca, que aceitará, e também as Universidades de Montpellier (França) e do Brasil (Rio de Janeiro) Ihe dedicaram idêntica distinção honorífica.

Membro do Instituto Internacional de Filosofia, assumiria em 1927 o significativo cargo de secretário (chairman) da Societas Spinoziana, por indicação pessoal de Léon Brunschvicg, o filósofo Judeofrancês que fundara este instituto internacional em 1897 e no qual Carvalho ingressa logo após se doutorar, em 1917. A forte atracção, muito explícita nos escritos de juventude, pela cultura científica e filosófica dos filhos de Israel e a sua difusão oblíqua à agenda ocidental da cultura europeia, conduzi-lo-á à dupla investigação das chamadas raízes espirituais do espinosismo - a persistente e desconcertante heterodoxia de um filósofo que, na sua fundada visão, «pensava por dentro em português» - e levá-lo-á a assumir relevante papel, sobretudo nas décadas de 1920-30, nesta Sociedade (Vereniging Het Spinoza), de Haia, impelindo-o a ingressar, como admite com justificado orgulho num relatório oficial preparado para a FLUC, no "círculo restrito de historiadores do espinozismo, de Israel e da mentalidade europeia do século XVII" (cf. OC, V: 37).

A convite de Carl Gebhardt, o maior especialista do filósofo duplamente expulso, editará então no Chronicon Spinozanum relevante material original, tal como «Espinosa perante a consciência portuguesa contemporânea» (Haia, vol. V, 1927); e no mesmo congresso desse ano da Societas, de 23-25 de Fevereiro, celebrando a inauguração da Domus Spinoziana, apresentou a tese, debatida com Durmin-Borkowsky, com o próprio C. Gebhardt e com A. Ravá, da ascendência portuguesa (da Vidigueira) da família Spinoza - tese que suscitou uma revoada polémica e a impugnação da precedente tese hispanista -, simpósio no qual esteve em risco de não participar dado o duplo pronunciamento republicano revolucionário no início desse mês e a dificuldade de obter vistos em Portugal 
Republicano, democrata, liberal, próximo do programa dialógico seareiro (do qual seria uma espécie de correspondente de mérito, em Coimbra), desenganou-se, após a breve experiência na década de 20, de qualquer pretensão de protagonismo na política activa, conquanto até 1923 fosse efémero dirigente regional do Partido Republicano da Reconstituição Nacional, liderado por Álvaro de Castro e Sá Cardoso - que, no entanto, cooptarão António Sérgio para Ministro da Instrução, em seu detrimento. Antissectário, o republicano idealista aproximara-se de Castro em finais 1919, sabe-se hoje melhor, na sequência da luta travada por si e pela corporação universitária contra a discricionária extinção da recém-criada Faculdade de Letras e contra aquele que a decretara, o efémero ministro democrático da Instrução pública, Leonardo Coimbra, apoiado num factotum, por ele inventado, o bacharel Joaquim Coelho de Carvalho, reitor nomeado pelo governo e desrespeitado pela corporação universitária, figura que no conjuntural gozo do presbitério da nova religiosidade civil deambulava, como escreveu o figueirense num libelo extraordinário (A Minha Resposta, 1919), "de guarda à porta férrea, arquiepiscopalmente" e gostava que o venerassem "como prelado universitário" (OC, VII: 4-9).

A proposta de aliança táctica ditou a efémera militância política de Carvalho. Refractário às legiões de formigas, o braço armado das falanges afonsistas, seu braço legal, adversário cada vez mais activo da violência política, da dissipação do erário público e da desordem cívica, defensor das liberdades públicas e dos privados direitos de propriedade (também intelectual), antigo simpatizante de António José de Almeida no qual continuará a admirar a "dignidade política" e a quem evocará como marco da história tribunícia e hábil reformista, conquanto bastasse "a reforma do ensino superior para conferir ao estadista a gratidão pública" (cf. OC, VIII: 223-224), Joaquim de Carvalho acabará assim por apoiar Álvaro de Castro e Sá Cardoso e ingressar no PRRN, a partir de 1920. Mas não acompanhará a posterior 
deriva nem ingressará no Partido Nacionalista quando reconstituintes e liberais na nova formação se fundirem em 1923.

Essa experiência vacinara-o contra qualquer ilusão prática. Desquita-se da Loja coimbrã Revolta, da maçonaria irregular, em 1924, embora continuasse a protestar, depois, já no interior da ditadura «nacional-seminarista», que para ele nunca chegará a expirar, pela instauração de uma República livre e democrática. Como registará numa epístola a Jaime Lopes Dias, em 1933, o neto de camponeses livres sempre regressará à terra da liberdade: "preso a princípios morais e políticos, não compreendo vida pública digna sem um parlamento, e seria para mim a maior honra da minha vida, aquela em que um dia, por eleição livre, eu pudesse no Parlamento traduzir, em palavras e actos, a voz obreira dos camponeses que me geraram".

Do afastamento da política activa resultaria, pela positiva, a possibilidade prática de desenvolver os inúmeros projectos do trabalho teórico em que se envolveu: "Por mim, obstinadamente continuarei na mesma rota, cada vez me interessando menos a acção política, e cada vez mais atraído para a acção obscura e impessoal de trabalhar para amanhã". Trabalhar para o futuro, numa universidade vigilante e punitiva e na opacidade cultural da década de 30, época em que escreve provavelmente a carta não datada ao poeta conterrâneo e amigo João de Barros, implicava "acarinhar e formar uma rodazinha de rapazes, com uma concepção grave da vida, direi quase de protestantes ou kantianos" (OC, VIII: 134).

Protestantes ou kantianos, leia-se melhor: treinado intelectualmente no confronto das ideias e educado, por dever e gosto do ofício escolar, na velha disputatio aristotélico-tomista, o mestre de filosofia abraçara a divisa nietzschiana, o ofício dos filósofos é protestar. Entende-se melhor, assim, o significado derradeiro de uma obra multímoda, quanto poliédrica, cuja complexidade de intersecção dos diversos campos analíticos (História, Filosofia, Cultura) ficou bem patenteada mais recentemente no acervo de comunicações apresen- 
tadas ao Colóquio Internacional Joaquim de Carvalho (Coimbra, 2014), e cujo signo é o de o labor do clérigo - neste sentido, o seu paciente trabalho de autêntico beneditino foi bem assinalado por Jaime Cortesão - que anota úteis e sistemáticas reflexões sobre deontologia pedagógica e ética universitária; ou se deixa influir por comentários firmes a anacrónicos regulamentos e praxes. "Quer queiramos, quer não", escreve com grande lucidez ainda em 1933, "começa a rodear-nos o crepúsculo, e para não nos volvermos cegos e anacrónicos carecemos harmonizar as formas docentes com o sentido da nossa época", replicando à crescente especialização e verticalização dos saberes e à queda do referente horizontal das ideias gerais, "coisas fáceis para nós, professores da Universidade de Coimbra, porque recebemos uma herança, que não se improvisa: a experiência histórica. Aprendemos através da nossa existência multissecular a distinguir o rito caduco do ídolo indestronável (...) sabemos que as reformas passam e só permanece o amor da ciência e do ensino, e por o sabermos é que não admitimos hierarquias no nosso seio e nos congratulamos sempre com a vinda dos que nos continuam e excedem" (OC, V: 186).

Compreende-se pois o modo como, entre os pares, o reconhecimento dos seus méritos invulgares cedo assomou. Os sinais são amplos. Desde logo, para o que particularmente interessa aqui, na indigitação para director da Biblioteca Geral, aos trinta e poucos anos de idade. Através dos ofícios da BGUC - socorremo-nos da informação escrita disponibilizada por cortesia do actual vice-director da instituição, Dr. António Eugénio Maia Amaral - pode seguir-se a sua actividade administrativa, não muito diferente da dos seus predecessores, Porém, a sua continuidade será posta em causa pelo decreto 15.465, que estipulava o respectivo exercício "durante as horas regulamentares de serviço". Joaquim de Carvalho, com uma agenda profissional mais do que assoberbada que lhe inibia o cumprimento de horários fixos na Biblioteca, apressou-se a pedir a demissão, em 16 de maio de 1928, mas o pedido obteve parecer 
negativo da Direcção-Geral e nesse sentido foi despachado pelo Ministro da Instrução Pública, tendo retomado o demissionário as suas funções a 1 de Julho, no próprio dia em que teve conhecimento do indeferimento. Mas entre a documentação da Biblioteca Geral nada se encontrou ainda que esclareça o processo da sua exoneração do cargo, em 1931. Não existe ofício algum dirigido ao Reitor sobre o assunto, porque o decreto de exoneração, de 7 de Agosto, o apanhou de férias. Da parte do governo, a forma de conseguir esta exoneração foi ardilosa: mudou-se a forma de nomeação dos Directores (por escolha do Ministro da Instrução Pública dentre dois professores da Faculdade de Letras, em comissão por dois anos) e, ipso facto, extinguia-se o lugar de Director efectivo (art. $.^{\circ} .^{\circ}$ do decreto 20.180 de 7 de Agosto - Diário do Governo, I série, n. ${ }^{\circ} 182$, 7-VIII-1931: 1832).

Mas o que por entre os trâmites burocráticos se camufla é a real motivação política para tal decisão. Ora, tratava-se de claro um processo de saneamento político correlato e indiciador, como hoje se sabe, do que seria a posterior extinção da Imprensa da Universidade e que por várias vezes se esboçara no conselho dos ministros do ditador - etapas ambas de uma estratégia de isolamento, não só do artífice intelectual, mas mormente do seu enorme influxo intelectivo, por via daquela que foi, durante a sua direcção, a mais influente editora da literatura científica e cultural do país.

Alfredo Pimenta, assaz próximo do Ministro da Instrução, Gustavo Cordeiro Ramos, irá narrar a Carvalho, na primeira pessoa e reportando-se à melhor fonte do caso, com a maior probabilidade a do próprio ministro, com o qual mantinha as melhores relações pessoais, os dados de uma "história que pode servir-lhe para apreciar os homens". Seguindo o seu relato, "quando foi da greve académica que se deu como estimulada pelo meu amigo, no Conselho de Ministros, propôs-se a sua demissão de Administrador da Imprensa, mascarada com a dissolução da Imprensa. O Gustavo Ramos, alegando 
o prestígio da Imprensa e o seu prestígio pessoal e administrativo opôs-se terminantemente. Dias depois, como se voltasse a insistir no caso, o Gustavo Ramos decidiu demiti-lo de Director da Biblioteca". Reputado ou imputado como o mentor da greve académica de 1931, Carvalho passou a ter como outro inimigo de estimação, no próprio conselho de Ministros e além da consabida acrimónia do «ânimo do César», o titular da Justiça, Manuel Rodrigues Júnior - antigo correligionário de Carvalho, na extinta República parlamentar, no Partido dos reconstituintes e que entretanto se bandeara para as doçuras inquisitoriais da Situação. Por isso se entende que Carvalho bem identifique todos os contornos da trama, quando em 1933 escrever a Pimenta, "reservo para uma cavaqueira, em Lisboa, a explicação profunda da atitude do homem da justiça. Surpreendeu-me em todo o caso, porque aqui, foi um momento nessa saleta que por minha mão - a pedido dele, claro - fez a sua entrada na política, acompanhando o Álvaro de Castro, etc. etc." (Cartas de Joaquim de Carvalho a Alfredo Pimenta, 2016: 219).

Contornos que Pimenta não deixa de esmiuçar, ao afastar pessoalmente Cordeiro Ramos, com o qual Carvalho também estabelece cordiais relações profissionais e lhe é credor até de certas atenções, de qualquer responsabilidade objectiva no caso: "Quando foi da amnistia, como o Ramos, antes de a votar, desejasse saber quem era beneficiado, o Manuel Rodrigues observou -Ihe: é singular que V. Ex. ${ }^{a}$ esteja com isso, quando não foi capaz de tirar a casa do administrador da Imprensa da Universidade, tendo ele instigado a greve. Ao que o Gustavo Ramos respondeu que o não fizera porque não deveria fazê-lo" («Cartas de Alfredo Pimenta para Joaquim de Carvalho», Revista de História das Ideias, 9, t. II, 1987: 994).

O papel mais visível e influente do bibliófilo, ocorreu não tanto enquanto bibliotecário mas enquanto editor universitário e científico, mormente na administração da Imprensa da Universidade. Como editor e copioso comentador, destacou-se na promoção e edição 
crítica das obras arcanas - muitos materiais e fontes para a história cultural, científica e técnica do país e da Península, entre os quais, para a própria História da Universidade de Coimbra, como são os casos das resenhas de autoria de Francisco Carneiro de Figueiroa ou de Francisco Leitão Ferreira. E, sobretudo, investindo no estudo minucioso dos curricula da escola universitária medieval e moderna e mesmo na dissecação da anatomia simbólica dos seus regulamentos e rituais. Essa aspiração a um permanente desafio, a um sapere aude, melhor transparece nos seus textos de estudo ou de homenagem académica a colegas e antigos mestres: o ideal cosmopolita, o ter mundo, é uma das determinações fundamentais da sua consciência. De um pedagogo do início do século XVIII, Martinho de Mendonça, e das suas viagens europeias escreverá este trecho exemplar: "Podendo ter sido, pela inteligência, pelo bom senso e até pela posição social, um renovador da cultura, como Jacob de Castro Sarmento, um crítico como Verney ou um mentor do ensino público como Ribeiro Sanches; o seu regresso granjeou-lhe apenas uma admiração fácil e provinciana" (OC, VII: 7).

É essa recusa liminar da provinciana autocontemplação e da pequena bajulação e é esse ter mundo, rumo a uma kantiana e idealizada cosmopolis, que o impelem a assumir, face a um interlocutor, a orientação determinante que inculcou, enquanto director, na «sua» Imprensa da Universidade: “Fui apenas o regisseur, preparando a arena para os outros fazerem as habilidades. Este era o meu dever. Se quiser saber a minha atitude e sua fundamentação leia o que Renan diz no Avenir de la science sobre a função das pequenas tipografias sábias. Aí verá a explicitação filosófica - ou se quiser outra razão, pense nos humanistas do séc. XVI, doublés de artistas ou artífices, que ao imprimir diziam consigo sic etiam do ceo". Ainda por palavras suas, "foi uma forma de ensino a que eu fiz: respeito pela inteligência alheia; cuidado na inversão dos papéis: ardor no desejo de mostrar que o nosso País é civilizado, e como tal não entoa uma única melodia, mas 
é um coral de vozes diversas; que sobre todos há a Pátria comum, que nenhum exprime na sua essência própria, e todos concorrem para a dignificarem; que à fidelidade àquilo de sempre cumpre dar lugar à inovação juvenil e à heterodoxia solitária; que era dever que o nosso País concorresse com os demais com os grandes corpos - Escritores Portugueses - Cronistas, etc. - que todos os grandes países possuem, etc. Sei, como ninguém, onde estão os defeitos; mas esses defeitos, pense bem, são os da grei e sobretudo relevantes das carências e dos lapsos da nossa cultura actual" (Cartas de Joaquim de Carvalho a Alfredo Pimenta [129]: 251).

Mais universitário do que «intelectual», mormente a partir de meados da década de 1930, na época da agitação polémica dos grandes manifestos de e sobre os intelectuais em torno da Trahison des clercs (1927), de Benda, Carvalho não descurara a intervenção cívica, particularmente activa na República e nos primeiros anos da ditadura em resistência à consolidação daquilo que designava nacionalseminarismo, afinal o nacional-situacionismo que deparara nas universidades com terreno propício para medrar e uma legião disponível e acrítica de servidores, mais ou menos previamente inscritos no partido antipartidos, mais ou menos colaboracionistas, e até algum capo para a execução programática. Campo, relembre-se (neste nosso tempo, no qual as palavras se banalizam na indiferença), lavrado pela repressão e censura e semeado pela promoção política, o favor e o favor, e pela propaganda intensiva.

Contra ventos e marés, objectivaria o desiderato de criar aí sólida escola de investigação filosófica, dentro e fora da universidade, activamente apoiando o movimento das universidades livres, contra vulgatas obedientes das filosofias de Escola, mas também um pouco à revelia da matriz maçónica da qual já se afastara formalmente, concatenando o seu mais amplo, constante e coerente combate cultural, como plataforma de estudo livre, reflexão, debate e difusão de ideias na exemplaridade de um clima universitário empenhado na 
construção metodológica da filosofia alicerçada num "estilo de ensino livre", como o caracterizaria o filósofo e psicólogo Sílvio Lima, aquele que foi, com Eduardo Lourenço, um dos seus mais reconhecidos e corajosos discípulos - precisamente por impugnarem o poder podre da repressão social e intelectual e reivindicarem uma epistemologia da liberdade. Um outro colega, o psicólogo Émile Planchard, que não foi seu directo discípulo, sobre ele deixou um valioso inédito (1990), por nós publicado em 2015:

«No princípio de 1937, a guerra de Espanha não tendo ainda acabado, chegava por mar a Portugal, com destino final em Coimbra, um jovem professor belga enviado pelo Reitor da Universidade de Lovaina que respondia a uma solicitação do governo português que procurava um especialista em ciências da educação (...) Depois de uma rápida volta pela velha e pitoresca cidade, o director da Faculdade [Eugénio de Castro], pediu ao motorista para me levar à casa do Prof. Joaquim de Carvalho que morava, naquela altura, na rua da Ilha, próxima da Universidade, onde ensinava, além das cadeiras de filosofia, a história Pedagógica, destinada, em princípio aos professores do ensino secundário e aos médicos escolares e da qual era director. Teria, eu próprio, de me encarregar da Psicologia escolar, da Pedagogia e da Didáctica gerais. (...) Logo, e por intuição discerni em Joaquim de Carvalho uma pessoa distinta e amável e um colega muito erudito [como] se escrevia e publicava na universidade congénere de Lovaina, no campo filosófico, e não imaginava eu, naquela altura que a minha estadia na cidade do Mondego duraria mais de um meio século e que prematuramente o ilustre mestre morreria em 1958. A casa onde ele vivia então estava a cem metros da sua Faculdade. Ainda o vejo chegar, a passos lentos, ao labor docente, a chover ou não chover, com o seu guarda-chuva na mão e um livro na outra. Ele vivia a maior parte do tempo fechado em casa, numa solidão monástica ou a dar aulas ou a investigar nas bibliotecas. Era, malgrado as suas absorventes tarefas intelectuais, um pai de família 
muito dedicado, tendo horror ao trabalho de grupo, e os seus [dez] filhos nunca foram para ele um entrave às suas actividades intelectuais. Saía pouco, amante do silêncio e da meditação. Exprimia-se com clareza e precisão, tanto na palavra como na escrita. Tinha culto da perfeição e da sobriedade, e nas suas obras, se manifestavam claramente estas qualidades. Sempre fiel às suas ideias e aos seus ideais aceitava sempre a discussão com a maior cortesia».

A solidão monástica, relevava afinal de um outro aspecto - o da autonomia moral, o sollen de qualquer sujeito epistémico. Não admira, pelo que se referiu, que Carvalho cada vez mais se distanciasse - e se os sinais são os mais claros a partir de 1935, tornam-se quase normativos já na década de 40 - daquilo a que denominava a mentalidade sala-dos-capelos, correlata, do modo ciente ou insciente, de uma mentalidade teológica que ao estudo dos factos opunha argúcia e "fogo de vista". Assumir esta atitude acarretava porém o risco do anátema da própria corporação universitária, pois se situava no plano resvaladiço de crescente incomodidade, à medida que imposta a ditadura, silêncios cúmplices e militantes invadiam as universidades.

Se fora ferido a vários golpes, na década de 30 , e se a partir de finais dos anos 40 se desvincula das cerimónias protocolares e recusa comparecer na sala dos Capelos a não ser no estrito cumprimento do serviço de exames; na década de 50, está cônscio na nova "crise que há-de vir e se aproxima com mais terribilidade do que se imagina", no "período veloz de Contra-Reforma e de confessionalismo que estamos vivendo", entra em rota de colisão com a secção de filosofia e a Faculdade, onde sempre se Ihe impugnou a direcção, personificada na ascendente tutela de Miranda Barbosa.

Próximo da morte, numa das páginas soltas ou ditadas ao seu filho Joaquim, e que intitulava Memórias, talvez material preparatório do livro não escrito, dá conta do desalento: "1956. A Universidade sob o sol-posto. O ensino e o amor ao estudo decaíram; em seu lugar surgiram os discursos, os cursos de férias e outras manifestações 
em que o saber real era substituído pelo ornamento verbal e pelo fingimento. Como a ignorância puxa ignorância, o resultado, aos trinta anos de sol-posto, foi a desconfiança e o repúdio pelo saber exacto. Foi sintomático, em Coimbra, o desprezo da Psicologia, obra do Miranda Barbosa". Ao perder a vis secularizadora do saber, o trilho da independência recíproca que desobrigasse a livre investigação científica e cultural dos preceitos e preconceitos de uma teologia anacrónica - pré-conciliar, note-se, não muito distante daquela, tomista, que a Deus Ihe impunha preceitos e preconceitos demasiado humanos, como com subtileza, antes de Nietzsche, já Espinosa notara -, derruía o veio da libertas philosophandi, fundamentação última para e de qualquer investigação. Daí que, na sua perspectiva, "o ambiente tornou-se clerical. Não era só o número de padres e de freiras, com seus hábitos; era sobretudo a transformação da mentalidade. O silêncio dos corredores, a compostura obediente, as reverências aos professores, a sensação da existência de uma fiscalização sempre presente, o anonimato espiritual, a indiferença por tudo o que cá fora se discute e apaixona. Seminário e convento".

Admita-se a desilusão face ao projecto acalentado para uma universidade secularizada destinada à formação de espíritos e de cidadãos livres e não, como ocorria por imperativo ditatorial, para moldar súbditos: "Nesse ambiente a formação da mocidade não podia deixar de gerar seres mutilados e insignificantes. Do lado da ditadura, obediência: o prof. Providência na inauguração do curso de férias sintetizou tudo quanto disse - que esta era a «Universidade de Camões e Salazar» (...). Tudo assentava na ideia de que a descrença é antipatriótica e antissocial - e que a crença católica é a alma do patriotismo português". Bem vistas as coisas, sob o invólucro científico renovado, em particular na Faculdade de Letras, na normatividade e no discurso universitários subsistiam cânones teológicos que a sobrevida dos ritos institucionais reforçava na semiótica clara de uma universidade confessional. 
Não se pode esquecer que em grande parte a nova Faculdade, em 1911, fora herdeira e legatária da extinta Faculdade de Teologia, e logo os seus iniciais mestres mais relevantes ou influentes eram ex-teólogos, com a excepção maior de Carolina Michaëllis, em cuja obra o jovem discípulo apreendera a crítica moderna conjugada com "a sedução perene dos grandes monumentos eruditos do século XVIII" (OC, V: 160). Em estertor de frequência, prestes a implodir à entrada do novo século, os mais destacados mestres teólogos começaram a orientar os seus cursos e investigações no sentido dos estudos históricos: o padre António de Vasconcelos (1860-1941), doutor em 1886, autor de vasta obra, primeiro teológica, depois desenvolvida na investigação gramática e finalmente em temas biográficos e da história da universidade, da qual é, depois de Carneiro de Figueiroa no século XVIII, o grande cultor; no sentido da História e Filologia, Joaquim Mendes dos Remédios (1867-1932), um dos patronos de Joaquim de Carvalho, doutorado em 1895, hebraísta e historiador da literatura, fundador da Revista da Universidade. Outros mesmo, a despeito de uma violenta conversão ao novo credo positivista e republicano, como Alves dos Santos (1866-1924), o outro patrono de Carvalho que introduz em Coimbra e no país a Psicologia experimental, na prática em obediência a um programa fisiométrico paredes meias com o eugenismo triunfante, não deixaram de ser expositores os mais escolásticos, o discípulo o escreveu, como que a sugerir que, tal como as rãs nos charcos ou mariposas em frores, também as metamorfoses da intolerância são larvares.

Por outras palavras, fora este mesmo o sentido preciso que o combate cultural que Joaquim de Carvalho, o clerc secular e universitário, protagonizou no interior de uma corporação ensimesmada: internacionalizar, europeizar, difundir, estudar, uma velha cultura cujas rotineiras abordagens metodológicas, demasiado subservientes à matriz historicista e filológica ou reféns da fonte literária ou literarizada, perdiam eficácia face à renovação historiográfica da cultura 
(com novos instrumentos conceptuais, tais como as problemáticas, as mundividências, os complexos culturais, as atitudes intelectuais, as conjunturas, a analogia) que ele próprio propunha. $E$ indo nesse sentido, nada mais dramático, para o ter mundo de Joaquim de Carvalho, do que a carência de uma filosofia livre, medrada no viveiro do confronto e da contradictio; e a ausência (ou recalcamento) de práticas culturais e sociais de uma enraizada cultura filosófica democrática ou, até, de uma cultura cidadã da política, modo de dizer, de uma cultura política da cidadania, o ar libertador que espíritos livres requerem para respirar (Espinosa, Tratactus Theologico-Politicus, XI). 